\title{
マイクロ市松パターンが筋芽細胞の配向に与える影響
}

\author{
高橋 優輔*1, 杉本 健太 ${ }^{* 2}$, 日野 遥 ${ }^{* 1}$, 橋本 成広*1
}

\section{Effect of micro checkered pattern on orientation of myoblast}

\author{
Yusuke TAKAHASHI ${ }^{* 1}$, Kenta SUGIMOTO*2 ${ }^{* 2}$ Haruka HINO*1 ${ }^{* 1}$ and Shigehiro HASHIMOTO*1 \\ ${ }^{* 1,{ }^{*}}$ Department of Mechanical Engineering, Kogakuin University \\ 2665-1 Nakanomachi, Hachiouji-shi, Tokyo 192-0015, Japan
}

Received: 18 April 2017; Revised: 14 June 2017; Accepted: 28 September 2017

\begin{abstract}
Control technique of orientation of a biological cell is expected to be applied to tissue engineering. It is known that morphology of the scaffold affects the cell behavior. For example, the micro stripe pattern can control cell orientation. The effect of aspect ratio of the micro checkered pattern on cell orientation has been investigated in the present study. The dimension of each unit of the micro checkered pattern is as follows: the length is $10 \mu \mathrm{m}$, and the height is $0.7 \mu \mathrm{m}$. Variation has been made on the width of the micro pattern: $5 \mu \mathrm{m}$ (A), $8 \mu \mathrm{m}$ (B) and $10 \mu \mathrm{m}(\mathrm{C})$. Each type of repeated micro pattern was formed in the square area of $500 \mu \mathrm{m} \times 500 \mu \mathrm{m}$. The micro pattern was made of the negative photoresist material (SU-8 2) coated on a glass plate by the photolithography technique. $\mathrm{C} 2 \mathrm{C} 12$ (mouse myoblast cell) was cultured for 24 hours on the micro pattern. The angle between the longitudinal axis of each cell and the width of the micro pattern was measured on the microscopic image. In each pattern, the average angle was as follows: 62.8 degrees on A, 50.2 degrees on B and 41.2 degrees on $\mathrm{C}$. The experimental results show that the aspect ratio of micro checkered pattern controls cell orientation.
\end{abstract}

Keywords : Biomedical engineering, Myoblast, Cell orientation, Micro checkered pattern, Photolithography technique

\section{1. 緒言}

筋芽細胞は，増殖・分化することで筋管と呼ばれる収縮能を持った細胞になる．筋管は微小な電気刺激によっ て収縮することが可能であり，バイオアクチュエータとして工業的に応用されることが期待されている. Fujita らは MEMS デバイスと骨格筋細胞を組み合わせたバイオアクチュエータの作製を行っている (Fujita et al., 2011). 一方で, Tanaka らはマイクロシステムと心筋細胞を用いてバイオポンプの作製を行っている (Tanaka et al., 2006). バイオアクチュエータの性能の向上を目指すためには，組織へ異方性を付与することが重要である．組織へ異方 性を付与寸るためには，細胞レベルでの配向の評価を行う必要がある.

細胞は接着基板の形状を感知して様々な挙動を示すことが知られている. 細胞工学の分野ではマイクロ加工技 術を応用して,さまざまな形状のマイクロパターンを作製し細胞の挙動に与える影響について検討を行っている. Wei らは三角形や四角形などのさまざまな形状を作製したマイクロパターン上で間葉系幹細胞を培養し, 脂肪細 胞の分化一の影響を報告している (Song et al., 2011). 配向に着目した研究では, 線状のマイクロパターン上で細 胞の培養を行う研究が多く存在する. Hino らはマイクロパターンの高さが細胞に与える影響について検討を行っ ており，0.7 $\mu \mathrm{m}$ から $20 \mu \mathrm{m}$ の範囲においてマイクロパターンが高いほど，細胞は配向性を示すことを報告してい る (Hino et al., 2014). また, Wang らはサブミクロンサイズのマイクロパターン上で細胞の配向について検討を 行っており, 細胞はナノサイズのパターン上でも配向性を示すことを報告している（Wang et al., 2010). 他にも, 線状のマイクロパターンが細胞の配向に与える影響について検討が行われている (Lam et al., 2006, Charest et al., 2007, Altomare et al., 2010)．これまでの研究では, 線状のマイクロパターンの高さや幅を変更して細胞の配向の検

No.17-00178 [DOI:10.1299/transjsme.17-00178], J-STAGE Advance Publication date : 10 October, 2017

*1 正員, 工学院大学大学院 工学研究科（产192-0015 東京都八王子市中野町 2665-1）

*2 工学院大学大学院 工学研究科

E-mail of corresponding author: ad15001@ns.kogakuin.ac.jp 
討を行っている.しかし，マイクロパターンの形状に着目し，細胞の配向について調べた研究は行われていなか つた.

そこで，我々はマイクロパターンのアスペクト比に着目した．先行研究で使用されているマイクロストライプ パターンは高さや幅が異なっていても，全てアスペクト比が無限大のパターンと考えることができる．つまり， 高アスペクト比のマイクロパターンを用いることで, 細胞はマイクロパターン方向に配向すると考えた. 本研究 では，筇管の配向の基礎検討として，マイクロ加工技術によってアスペクト比の異なる 3 種類のマイクロ市松パ ターンを作製し，単一の筋芽細胞にどのような影響を与えるかを調査することを目的とした.

\section{2. 方 法}

\section{$2 \cdot 1$ 理論}

本研究では, 細胞はマイクロ市松パターンの対角線方向へ伸展すると仮定した. 寸なわち, 細胞の配向予想角 度を各四角形単位の対角線方向とした. また, 細胞の長軸方向角度はマイクロ市松パターンの横幅方向を $0^{\circ} と し$, 絶対值を用いて $0^{\circ}$ から $90^{\circ}$ とした（図 1). マイクロ市松パターンの対角線の角度 $\alpha$ は式 (1) で求めることがで きる.

$$
\alpha=\tan ^{-1}(L / W)
$$

ここで， $\alpha$ は配向角度， $L$ と $W$ はそれぞれマイクロ市松パターンの縦幅と横幅である. 縦幅と横幅の比を変え ることで，細胞の配向方向を変化させることが可能であると考えた.

(a)
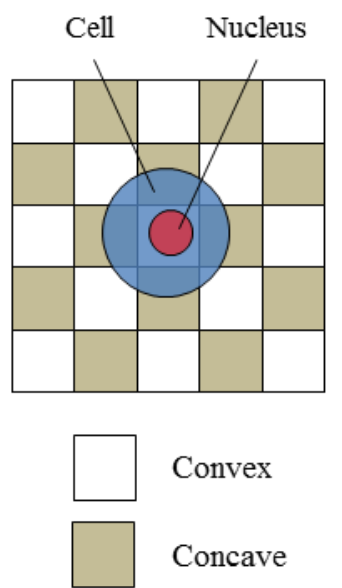

Convex

Concave

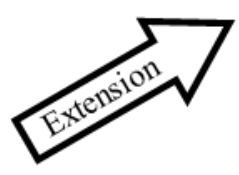

(b')
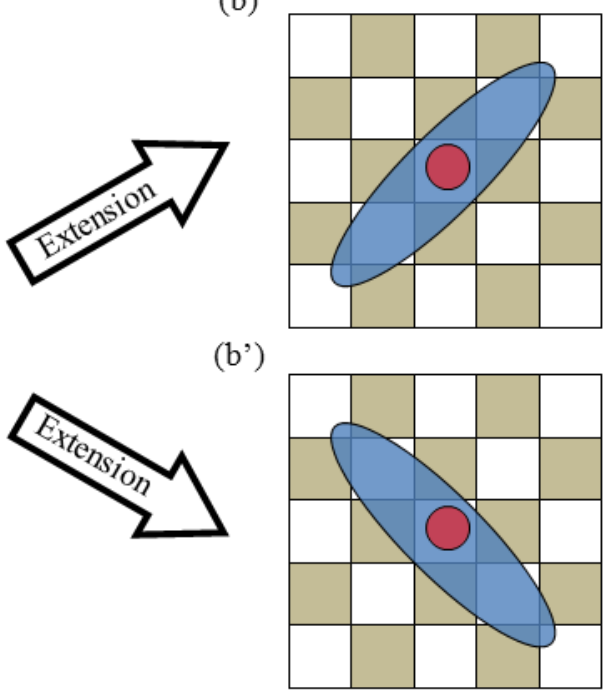

(c)

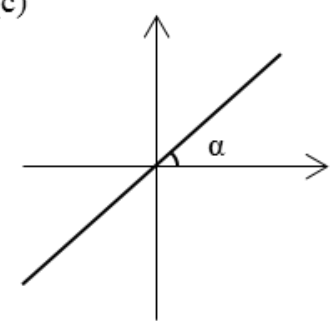

$\left(c^{\prime}\right)$

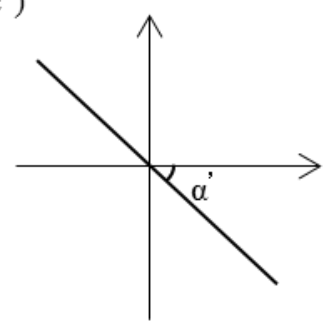

Fig. 1 Cell extension image. (a): Before extension on the scaffold. (b) \& (b' ): After extension on the scaffold. (c) \& (c'): Diagonal angle of checkered pattern.

\section{$2 \cdot 2$ マイクロパターン作製}

マイクロ市松パターンのアスペクト比が細胞へどのような影響を及ぼすか検討するために, 3 種類のマイクロ 市松パターンを作製した．浮遊状態の細胞は直径がおよそ $20 \mu \mathrm{m}$ であるため, マイクロパターンの溝に落ち込ん で閉じ込められることがないように, 高さを $0.7 \mu \mathrm{m}$, 縦幅を $10 \mu \mathrm{m}$ で固定した. 他方, 横幅を $5 \mu \mathrm{m}, 8 \mu \mathrm{m}, 10 \mu \mathrm{m}$ と変化させた. マイクロ市松パターンは 1 辺が $1 \mathrm{~mm}$ の正方形エリアを 4 分割し, それぞれ, $5 \mu \mathrm{m}$ area, $8 \mu \mathrm{m}$ area, $10 \mu \mathrm{m}$ area，そして，パターンを付与しないガラス面のみの Control area を作製した（図 2）. 


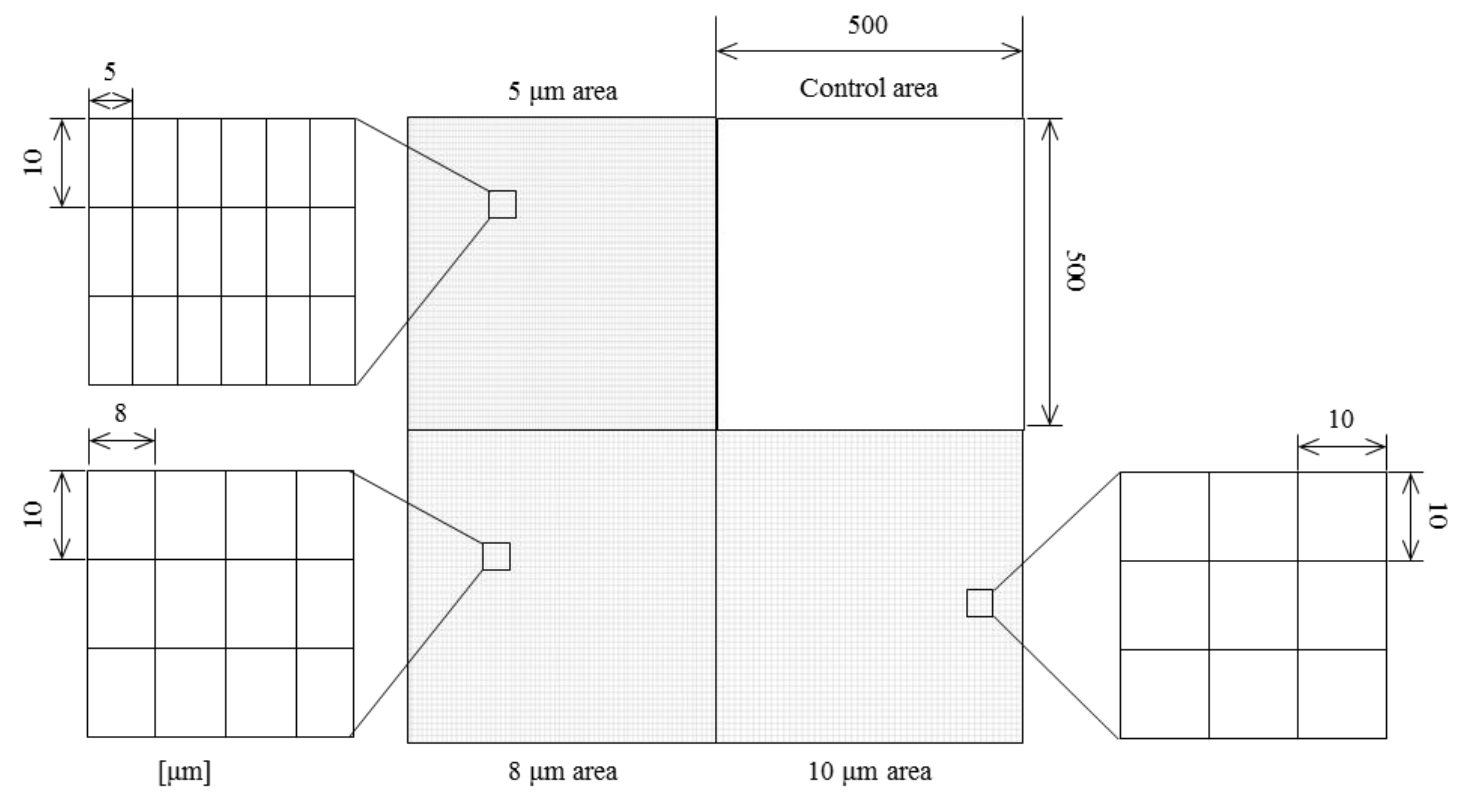

Fig. 2 Dimension of micro checkered patterns. Each area is $500 \mu \mathrm{m} \times 500 \mu \mathrm{m}$. Length $=10 \mu \mathrm{m}$, height $=0.7 \mu \mathrm{m}$. Variation of the width: 5,8 , and $10 \mu \mathrm{m}$. Control area does not have any micro patterns.

最初に，マイクロ市松パターンを効率良く作製するためにフォトマスクの作製を行った．フォトマスクは株式 会社千葉理科ガラスより購入した直径 $35 \mathrm{~mm}$ のテンパックスガラスを用いて作製した. 初めに, コンパクトエッ チャ（FA-1，株式会社サムコインターナショナル）によって $\mathrm{O}_{2}$ プラズマアッシング処理を行った. 次に, 電子ビ 一ム蒸着装置（JBS-Z0501EVC，日本電子株式会社）によってチタン薄膜を $100 \mathrm{~nm}$ 蒸着した. チタンを蒸着した 面に再度, コンパクトエッチャによって $\mathrm{O}_{2}$ プラズマアッシング処理を行った. 次に, 基板とレジスト材の接着性 を向上させるために, HMDS（1,1,1,3,3,3-Hexamethyldisilazane，東京化成工業株式会社）を本速 $3000 \mathrm{rpm}$ で 30 秒 スピンコートした．続けて，ポジ型レジスト材（OFPR-800LB，東京応化工業株式会社）を本速 $7000 \mathrm{rpm}$ で塗布 し， $95^{\circ} \mathrm{C}$ オーブン内で 3 分間プリベークを行った。続いて，レーザ直接描画装置（DDB-201，ネオアーク株式

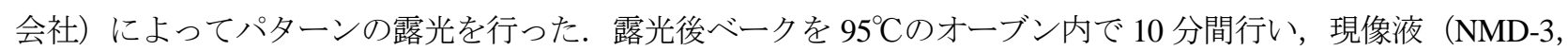
東京応化工業株式会社）に浸漬してパターンの現像を行った．続いて， Reactive Ion Etching（RIE-10NR，株式会 社サムコインターナショナル）にて $\mathrm{SF}_{6}$ と $\mathrm{Ar}$ ガスを用いたドライエッチングを行った. 最後に残存しているレジ スト材をアセトンで除去し，マスクを作製した。

次に，新しいガラスを用いて培養基板の作製を行った．直径 $35 \mathrm{~mm}$ のテンパックスガラスをコンパクトエッチ ヤで $\mathrm{O}_{2}$ アッシング処理を行い，ネガ型レジスト材（SU-8 2, MicroChem Corp.）を本速 7000 rpm でスピンコート

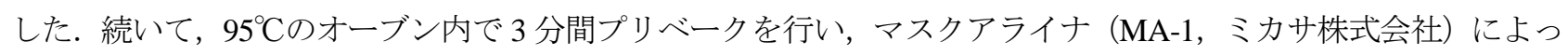
て露光した. 露光後ベークは $95^{\circ} \mathrm{C}$ 加温したオーブン内で 10 分間行い, 現像液 (SU-8 Developer, MicroChem Corp.) に浸漬し，6 分間現像処理を行った.レーザ顕微鏡（VK-X 200, 株式会社キーエンス）によって観察を行った（図 3). マイクロ市松パターンの測定は 4 枚の基板を用いて測定を行った.

それぞれのパターンの寸法と配向予想角度の誤差率は式（2）を用いて算出した（表 1).

$$
\varepsilon=\frac{|R-M|}{R} \times 100
$$

ここで， $\varepsilon$ は誤差率， $R$ は配向予想角度の理論值， $M$ は実測值を用いて算出した配向予想角度である．作製し たマイクロ市松パターンの配向予想角度の誤差率は $5 \%$ 以下であった. 

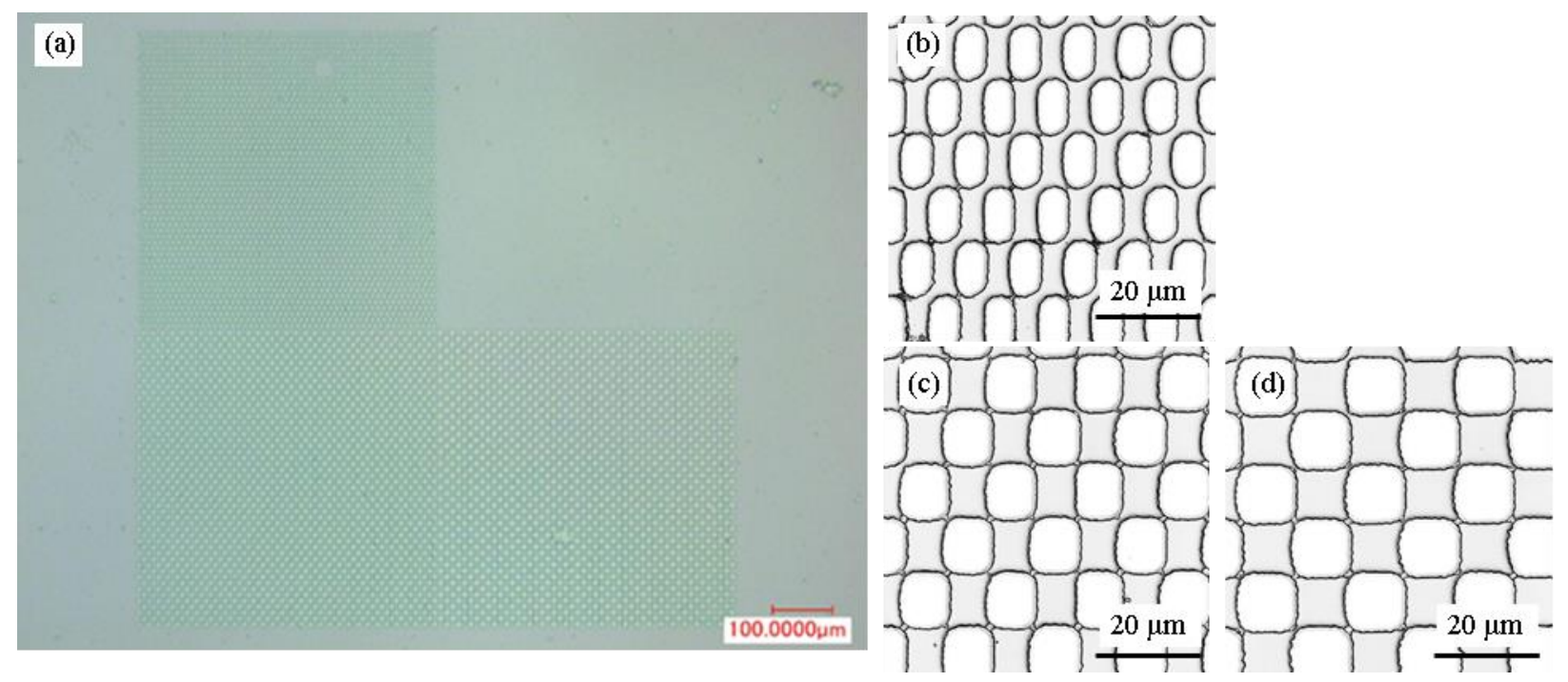

Fig. 3 (a): Laser micro scope image: overview. (b): Magnified $5 \mu \mathrm{m}$ area. (c): $8 \mu \mathrm{m}$ area. (d): $10 \mu \mathrm{m}$ area.

Table 1 Dimension of micro pattern in each group. $(\mathrm{n}=4)$

\begin{tabular}{c|c|c|c}
\hline \hline & $5 \mu \mathrm{m}$ area & $8 \mu \mathrm{m}$ area & $10 \mu \mathrm{m}$ area \\
\hline Length, $L[\mu \mathrm{m}]$ & $9.9 \pm 0.3$ & $10.9 \pm 0.3$ & $11.4 \pm 0.4$ \\
Width, $W[\mu \mathrm{m}]$ & $5.4 \pm 0.3$ & $9.0 \pm 0.5$ & $11.5 \pm 0.9$ \\
Height, $H[\mu \mathrm{m}]$ & $0.73 \pm 0.06$ & $0.76 \pm 0.09$ & $0.77 \pm 0.08$ \\
Actual orientation angle, $M$ [degree] & $61.1 \pm 1.0$ & $50.3 \pm 1.6$ & $43.5 \pm 1.4$ \\
Theoretical orientation angle, $R$ [degree] & 63.4 & 51.3 & 45.0 \\
Ratio of difference of angle, $\varepsilon[\%]$ & $1.6 \pm 0.0$ & $2.0 \pm 0.1$ & $2.3 \pm 0.1$ \\
\hline
\end{tabular}

作製した培養基板上で細胞培養を行うために, 生体適合性に優れた樹脂材料である PDMS (Polydimethylsiloxane, Dow Corning Corp）を主材と硬化剂を 10:1の割合で混合し，100ㄷのオーブン内で 10 分間硬化させた. その後， 直径 $20 \mathrm{~mm}$ のポンチでリング状に切り抜き，培養基板上に接着させることで壁面を作製した。

\section{$2 \cdot 3$ 細胞培養}

実験には継代数が 10 回以下のマウス横紋筋由来筋芽細胞（C2C12，DS ファーマバイオメディカル株式会社） を用いた．培地は D-MEM 基礎培地（Dulbecco’s Modified Eagle Medium，Thermo Fisher Scientific）にウシ胎児血清 （Fatal Bovine Serum， Sigma-Aldrich）を 10\%，抗生物質（Penicillin-Streptomycin, Thermo Fisher Scientific）を 1\% 添加した. 細胞は温度 $37^{\circ} \mathrm{C}, \mathrm{CO}_{2}$ 濃度 $5 \%$ のインキュベータ内で培養した. 細胞は $2000 \mathrm{cells} / \mathrm{cm}^{2}$ の濃度で播種を し，播種後 24 時間で 4\%のパラフォルムアルデヒドで 20 分間固定した。続いて，エタノール濃度 50\%，70\%， 80\%，90\%，95\%，99.5\%の順に 3 分ずつ脱水を行った. 脱水処理を行った後，マイクロスコープ（VHX-1000, 株式会社キーエンス）によって観察を行った（図 4). 実験は基板の処女面を用いて 4 回行った. 


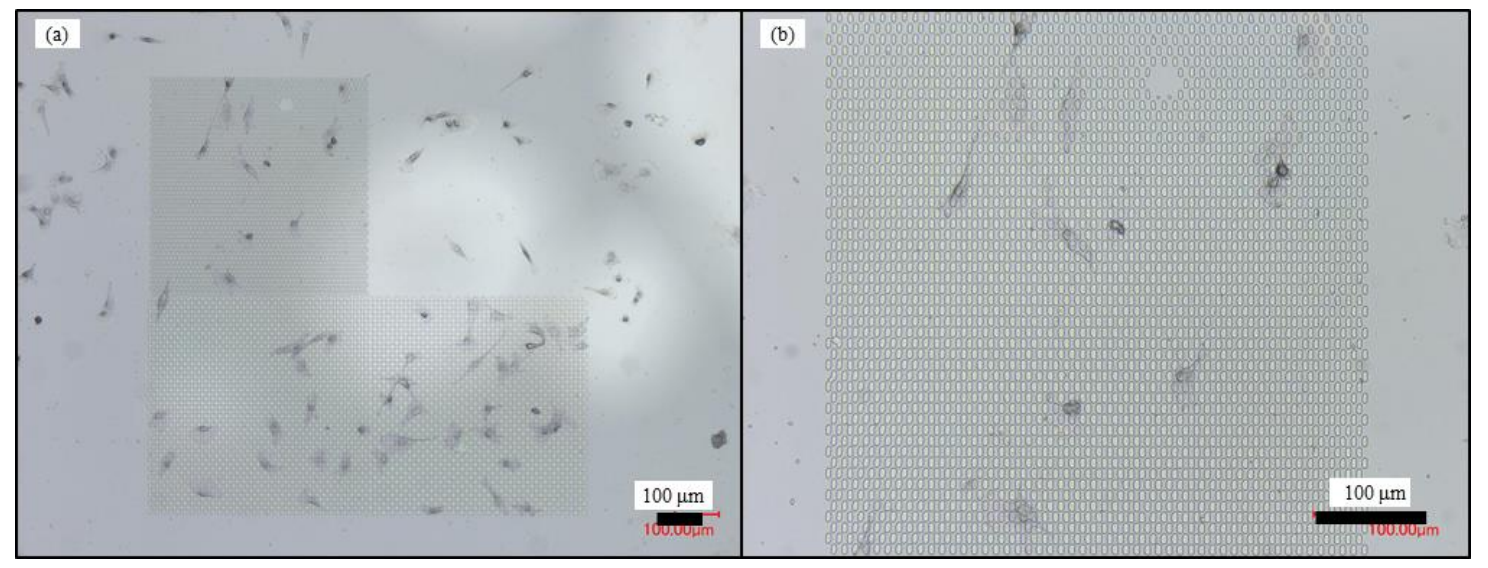

Fig. 4 (a): Microscope image after immobilization with paraformaldehyde . (b): Magnified $5 \mu \mathrm{m}$ area.

\section{$2 \cdot 4$ 評価方法}

初めに，本研究では SU-8 とガラスといった異なる材料の基板を使用している．そのため，材料表面の性質を 調べる必要がある. そこで, マイクロ加工を行っていないテンパックスガラスと全面に SU-8 2 を 7000 rpm でコ 一ティングした基板を用意し， $\mathrm{O}_{2}$ プラズマによる親水化処理前後の接触角を調べた.

細胞は常に移動や増殖などの挙動を示寸. そのため, 播種後 24 時間後の細胞では, 様々な形状の細胞が存在し ていることが考えられる，そこで，細胞の形状指数と細胞の角度について評価を行った．細胞の形状指数は輪郭 を囲った際に得られた細胞の長軸と短軸の比を用いることで以下のように定義した。

$$
S I=1-\frac{L_{S}}{L_{L}}
$$

ここで，SI は形状指数， $L_{L} ， L_{S}$ はそれぞれ細胞を楕円近似した際の長軸長さと短軸長さである. SI が 1 に近づ くにつれて，細胞が細長い形状をしていると考えることができる．また，SI が低い細胞は円形状をしており，角 度評価が困難である. そのため, 本研究では SIが 0.3 未満の細胞は評価の対象外とした. そして, ピアソンの積 率相関係数 $r$ を算出し, SI と細胞の角度の相関について検討を行った。

細胞の角度評価には汎用画像解析ソフトウェア ImageJ 用いた. それぞれの細胞の輪郭を囲み, 楕円近似した ときの長軸方向を細胞の向きとした. 本研究では, マイクロパターンが細胞の向きに及ぼす影響を調べるために, 隣接した細胞のいない単一細胞を解析の対象とした．また，細胞の一部分がマイクロパターン上から出ている場 合はマイクロ市松パターンが細胞に与える影響を正確に調べることができないと考え，除外した．算出した角度 から Control area と各マイクロ市松パターンとの差をスチューデント $\mathrm{t}$ 検定により, 有意水準 $\mathrm{p}<0.05$ を用いて算 出した．続いて，15刻みの細胞の存在確率を算出した．また，10 $\mu \mathrm{m}$ area と Control area では予測される平均角

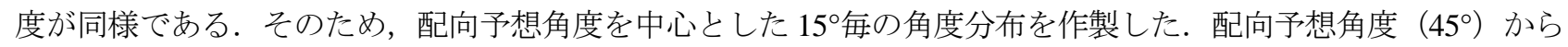
近い順に G1 から G6 までの角度グループを作製した（表 2)。これらのグループに存在する細胞の割合を用いて $10 \mu \mathrm{m}$ area と Control area の配向性の違いについて検討した. 配向性の評価として, カイ二乗検定によって, 各グ ループの均等分布値 $(16.67 \%)$ と実験值を有意水準 $\mathrm{p}<0.05$ によって評価した.

Table 2 Angle range of each group

\begin{tabular}{c|c|c|c|c|c|c}
\hline \hline & G1 & G2 & G3 & G4 & G5 & G6 \\
\hline \multirow{3}{*}{ Angle, [degree] } & $37.5-45.0$ & $30.0-37.5$ & $22.5-30.0$ & $15.0-22.5$ & $7.5-15.0$ & $0-7.5$ \\
& and & and & and & and & and & and \\
& $45.0-52.5$ & $52.5-60.0$ & $60.0-67.5$ & $67.5-75.0$ & $75.0-82.5$ & $82.5-90.0$ \\
\hline
\end{tabular}




\section{3. 結 果}

基板表面の性質を調べるために，親水化処理前後の超純水の接触角を測定した（図 5). ガラス上，SU-8 上と もに親水化処理を行うことで，超親水性の表面となった．このことから，ガラスと SU-8 の表面物理的性質は大 きな差はないとした.

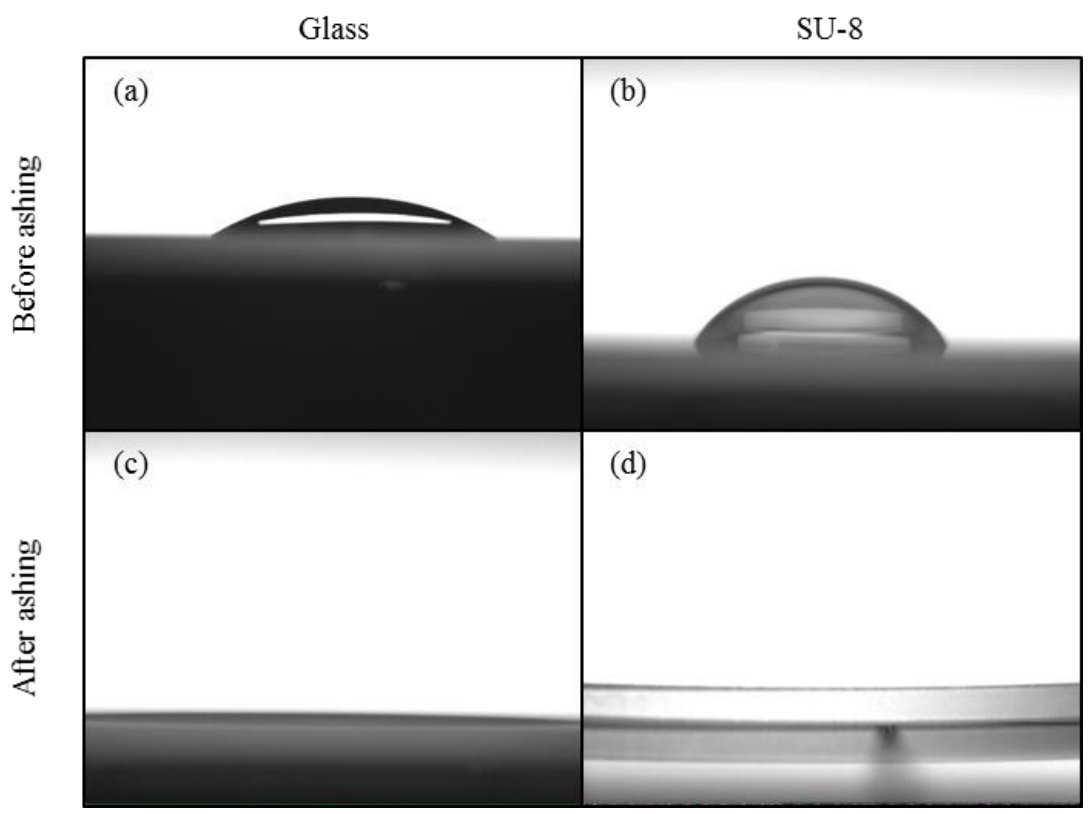

Fig. 5 Drop of pure water. (a): on the glass plate before ashing. (b): on SU-8 before ashing. (c): on the glass plate after ashing. (d): on SU-8 after ashing.

続いて, 細胞の角度とSIについて検討を行った（図 6).SIが 0.3 以下の細胞は角度評価が困難であるため除外 した. その結果， $5 \mu \mathrm{m}$ area， $8 \mu \mathrm{m}$ area， $10 \mu \mathrm{m}$ area，Control area それぞれの評価対象細胞数は 77, 107，84，94 となった. また, 全てのエリアにおける $S I$ と細胞の角度の相関係数 $r$ は $5 \mu \mathrm{m}$ area, $8 \mu \mathrm{m}$ area, $10 \mu \mathrm{m}$ area, Control areaにおいてそれぞれ，0.08，0.06，0.02，0.03 となり，SI と細胞の角度には相関はなかった。

続いて, 細胞の平均角度を算出した（図 7a). 細胞の平均角度は $5 \mu \mathrm{m}$ area, $8 \mu \mathrm{m}$ area, $10 \mu \mathrm{m}$ area, Control area において，それぞれ $62.8^{\circ} ， 50.2^{\circ} ， 41.2^{\circ} ， 45.8^{\circ}$ であった. Control area と比較して，5 $\mu \mathrm{m}$ area $と 8 \mu \mathrm{m}$ area では平 均角度に有意差が認められた。しかし，10 $\mu \mathrm{m}$ area では Control area との有意差は認められなかった。続いて, $15^{\circ}$ 刻みの細胞の角度分布を算出した (図 7b). $5 \mu \mathrm{m}$ area では細胞は $75^{\circ}$ から $90^{\circ}$ 方向に $46.7 \%$ の細胞が存在し, $8 \mu \mathrm{m}$ area では $45^{\circ}$ から $60^{\circ}$ に $27.1 \%$ の細胞が存在していた. $10 \mu \mathrm{m}$ area では $45^{\circ}$ から $60^{\circ}$ の $22.6 \%$ の細胞が存在していた. 一方で, Control area では細胞はランダムな方向に向いており, どの範囲においても $18.1 \%$ 以の細胞の存在にと どまった.

最後に, $10 \mu \mathrm{m}$ area と Control area の配向性の違いを検討するために, 配向予想角度を中心とした角度範囲にお ける細胞の存在率を算出した (図 8). その結果, $10 \mu \mathrm{m}$ areaでは $\mathrm{G} 1$ に $24.4 \%$ の細胞が存在しており, 均等分布 值と比べて有意に高かった. また, G6 では細胞の存在率は $8.5 \%$ となり, 均等分布值と比べて有意に低かった. G2 から G5 では均等分布值と有意差は認められなかった。一方で, Control area ではすべてのグループ（G1 から G6）において均等分布值との有意差は認められなかった. 

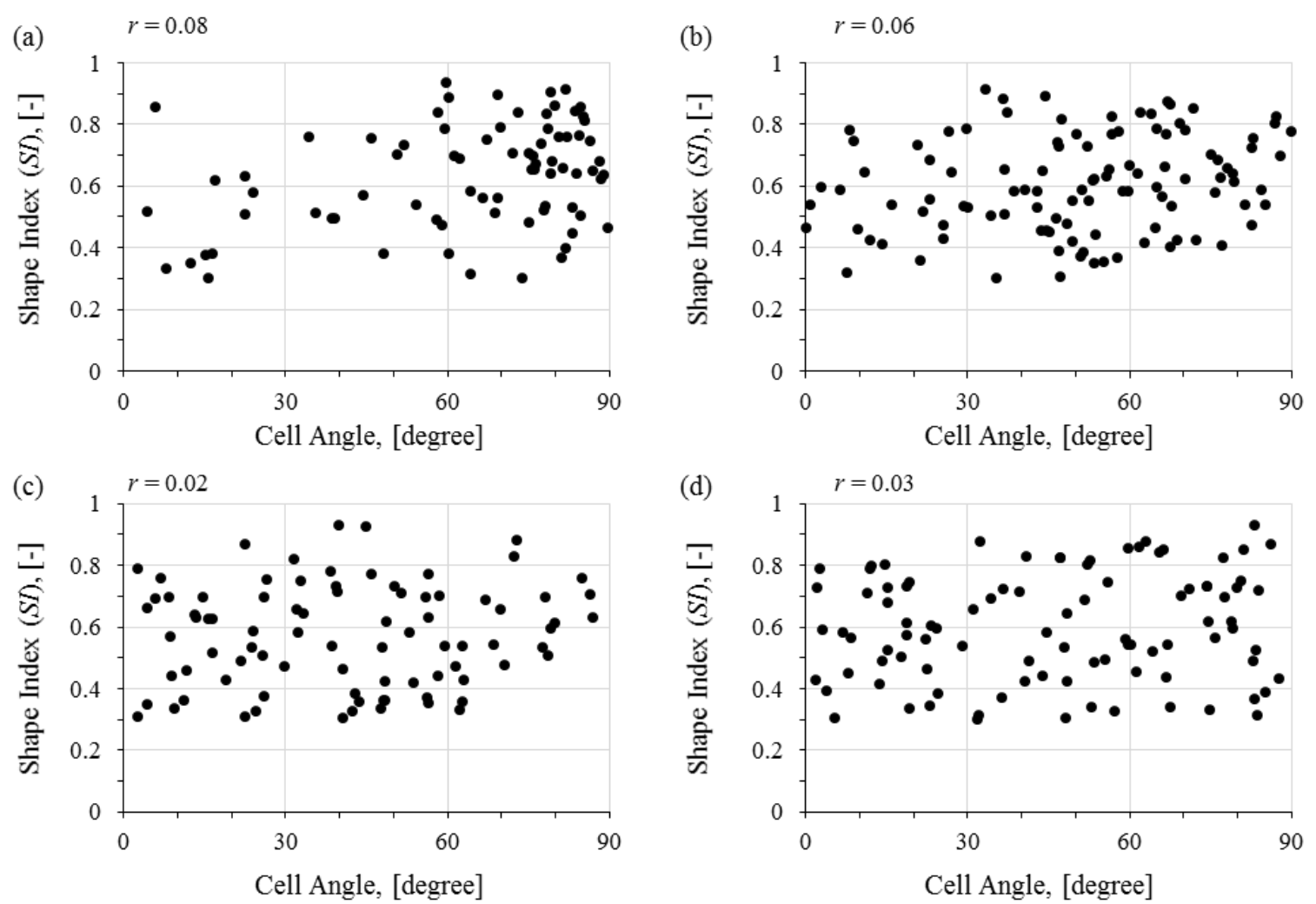

Cell Angle, [degree]

Fig. 6 Shape index (SI) vs. cell angle. (a): $5 \mu \mathrm{m}$ area, (b): $8 \mu \mathrm{m}$ area, (c): $10 \mu \mathrm{m}$ area, (d): control area. $r$ : correlation coefficient.

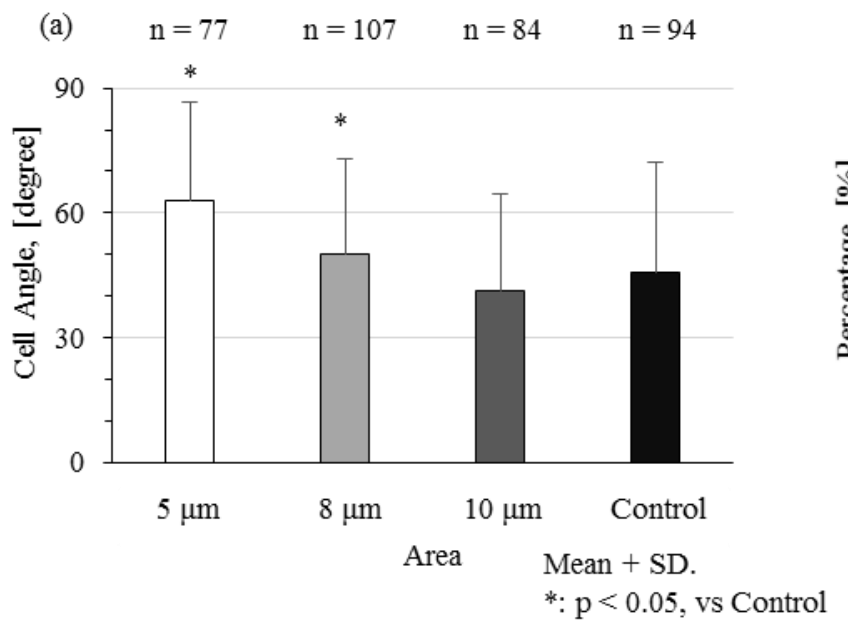

(b)

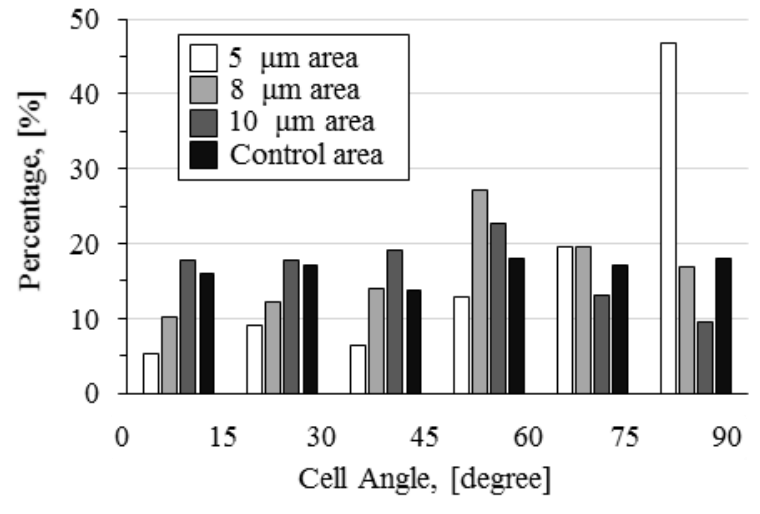

Fig. 7 (a): Average of cell angle. Bar shows standard deviation. * significant difference vs control. (b): Percentage of each cell angle range. 


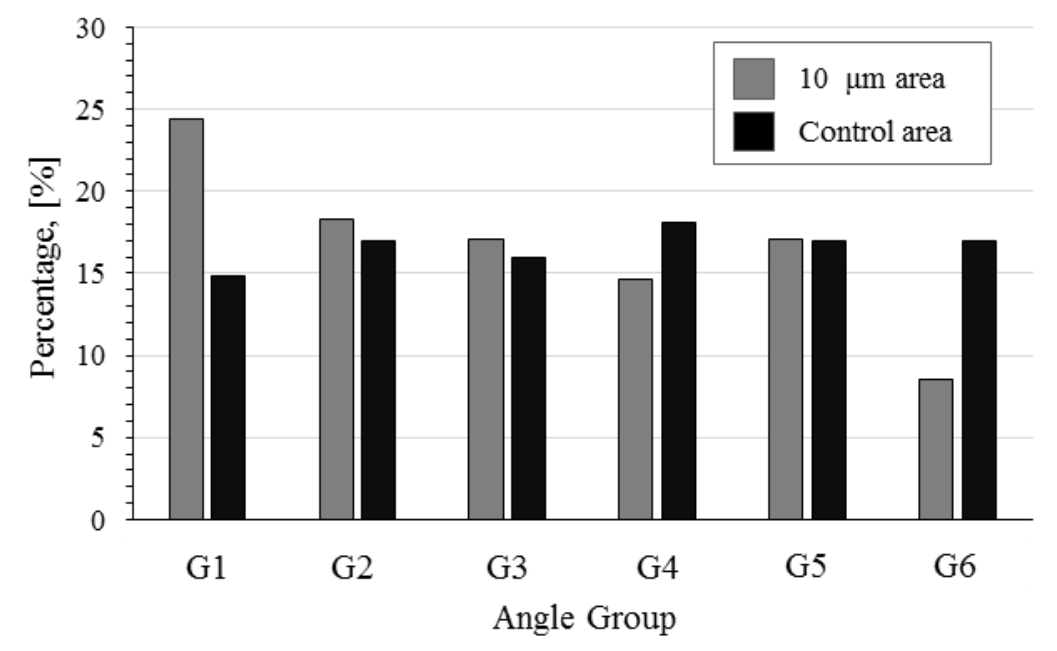

Fig. 8 Percentage of each cell angle group (see Table 2).

\section{4. 考察}

本研究では，細胞はマイクロパターンのアスペクト比によって配向方向に影響を受けると考え， 3 種類のアス

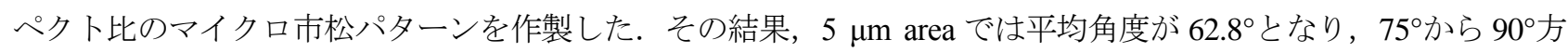
向に $46.7 \%$ の細胞が存在した. また， $8 \mu \mathrm{m}$ area では平均角度が $50.2^{\circ}$ となり， $45^{\circ}$ から $60^{\circ}$ 方向に $27.1 \%$ の細胞が存 在していた．そして，10 $\mu \mathrm{m}$ area と Control area では平均角度が $41.2^{\circ} ， 45.8^{\circ}$ と同等の值を示した．しかし，10 $\mu \mathrm{m}$ area では $45^{\circ}$ 方向（G1）に 24.4\%の細胞が存在し，均等分布值と比べて有意に高い傾向があり，また，G6に $8.5 \%$ の細胞が存在し, 均等分布值と比べて有意に低かった，一方で, Control area ではすべての範囲において均等分布 值との有意差が認められなかった.

マイクロ市松パターンはガラス基板上に SU-8 を塗布して作製した．そのため，接着基板表面はガラスと SU-8 といった異なる材料となっており，表面の性質によって異なる結果が現れた可能性がある．そこで，基板表面の 性質を調べるために, 親水化処理前後の超純水の接触角を測定した. ガラス上, SU-8 上ともに親水化処理を行う ことで，超親水性の表面となった．このことから，ガラスと SU-8 の表面物理的性質は同様であると考えた.

本研究で播種から 24 時間後の細胞について評価を行った. 細胞は常に移動や伸展といった挙動を示している. そのため, 評価する時間のタイミングによって細胞の角度が異なる可能性がある. そこで, 細胞を楕円近似した 際の長軸長さと短軸長さを用いて SI を算出した. SI が低い細胞は円形状となり, 細胞の角度を算出することが困 難である. そのため, SI が 0.3 以下の細胞を除外して評価を行った，その結果，すべてのエリアにおいて，SI と 細胞の角度には相関がなかった.このことから, 全体的な細胞の角度分布は時間経過に依存しないと考えられる. しかし，単一細胞では時間経過とともに角度変化やSIの変化があるため，今後の検討課題と考えられる.

$5 \mu \mathrm{m}$ area， $8 \mu \mathrm{m}$ area， $10 \mu \mathrm{m}$ area において, 細胞の平均角度は配向予想角度とほぼ同等の結果を得た. 寸なわ ち，それぞれのマイクロパターン上で異なる配向を示した． $5 \mu \mathrm{m}$ area の配向予想角度は $61.1^{\circ}$ であったが, $75^{\circ}$ か ら 90のの範囲に 46.7\%の細胞が存在していた. つまり， $5 \mu \mathrm{m}$ area 上において細胞はマイクロ市松パターンの長軸 方向に配向を示した.この結果は線状パターンを用いた先行研究の結果と類似している (Hino et al., 2014). マイ クロストライプパターンは線幅が数 $\mu \mathrm{m}$, 長さが無限大と考えることが可能であり, アスペクト比が無限大のマ イクロ市松パターンであると考えることが可能である. このことから, 基板表面パターンのアスペクト比が 2 以 上のマイクロパターン上において細胞は，ほぼマイクロパターンの長軸方向へ配向すると考えられる.

$8 \mu \mathrm{m}$ area の配向予想角度は $50.3^{\circ}$ であり, $45^{\circ}$ から $60^{\circ}$ の範囲に $27.1 \%$ の細胞が存在していた. このことから, $8 \mu \mathrm{m}$ area 上では細胞はマイクロ市松パターンの対角線方向に配向していることがわかる. また，低角度 $\left(0^{\circ}\right)$ 方向よ りも高角度 $\left(90^{\circ}\right)$ 方向に向いている細胞が多かった. このことから, 接着基板に長軸と短軸が存在するとマイク ロパターンの長軸方向に細胞は伸展していきや寸い傾向にあると考えられる. 
$10 \mu \mathrm{m}$ area の配向予想角度は 43.5であり，ほぼ，Control area と同等であった．そこで，45。を心とした細胞 の角度分布を用いて $10 \mu \mathrm{m}$ area と Control area の差を検討した. Control area では，細胞が G1 から G6 のそれぞれ の範囲に均等に分布しており, 全ての範囲において均等分布値と有意差は認められなかった. しかし, $10 \mu \mathrm{m}$ area では G1 の範囲に 24.4\%の細胞が存在しており, 均等分布值と比べて細胞の存在率が有意に高かった. そして, G6 では均等分布值と比べて細胞の存在率が有意に低かった. これらのことから, 細胞は等方的なマイクロ市松パ ターンの影響を受けており，配向予想角度方向に配向する傾向があることがわかる.

本研究では，マイクロ市松パターンの影響のみを調べるために隣接している細胞を除外して検討を行った．播 種から 24 時間後では, 細胞の増殖もあまり起こらず, 単一の細胞での評価には適していた. 配向している細胞に 他の細胞が隣接すると，細胞間の相互作用によって同様の方向に伸展していく，そのため，単一細胞で細胞の配 向が見られることで, 増殖していく過程においても細胞はマイクロパターンの影響を受け，配向を示寸と考えら れる．また，筋芽細胞は融合し分化する能力を持っている．筋管の配向は収縮方向の制御などに必要である.

Sugimoto らは同様の形状のマイクロパターンを用いて筋管の配向について評価を行っている (Sugimoto et al., 2016）。その結果，筇管は対角線方向または長軸方向へ配向を示寸ことが報告されている. 今後は隣接している細 胞についての検討や，筋管の配向について検討を行うことで，基板形状と細胞の配向について詳細な検討を行う ことが可能となる.

細胞は焦点接着斑やアクチンフィラメントを介して外部の環境を感知していると考えられている. これまで行 われてきた研究では, マイクロパターン上で細胞を培養し, アクチンフィラメントと核を染める方法が用いられ ている（Song et al., 2006, Charest et al., 2007, Wang et al., 2010）。しかし，これらの研究ではマイクロパターンと染 色細胞を同時に示している画像はない. マイクロ市松パターンでは細胞の接着位置やアクチンフィラメントの方 向をみることで詳細な配向のメカニズムについて検討することができる. そのため, マイクロ市松パターンと細 胞の染色画像を同時に取る必要がある. 今後の検討課題である.

先行研究では, マイクロストライプパターンを用いて細胞の配向について検討を行っていた．しかし，マイク ロストライプパターンはどのパラメータを変更してもストライプ方向に配向を示していた，そのため，マイクロ パターンのどのパラメータに反応して細胞が配向を示していたのかわからなかった．本研究では新たな視点から 細胞の配向を検討寸るために, マイクロ市松パターンのアスペクト比を変えて実験を行った. 本研究の結果から, 細胞は基板の表面形状のアスペクト比によって配向方向が決定されたと言える. 今後は分化後の筋管の配向や筋 芽細胞の移動や伸展について検討を行うことで，マイクロパターンによる細胞の配向のメカニズムをさらに詳細 に検討することが可能となると考えている.

\section{5. 結 言}

縦横比を $10: 5,10: 8,10: 10$ と変えたマイクロ市松パターンを作製し, 筋芽細胞の配向に対する影響を調べ た. その結果，3 種類のマイクロパターンにおいて以下のような互いに異なる影響を観察した.

（1） $5 \mu \mathrm{m}$ area では，細胞の平均角度は $62.8^{\circ}$ となり，マイクロ市松パターンの対角線方向 $\left(61.1^{\circ}\right)$ と近い方向 であった。しかし, 細胞の配向方向の大部分はマイクロ市松パターンの対角線方向ではなく, マイクロ市松パタ ーンの長軸方向 $\left(75^{\circ}\right.$ から $\left.90^{\circ}\right)$ であり，この方向に $46.7 \%$ の細胞が存在していた.

(2) $8 \mu \mathrm{m}$ area では, 細胞の平均角度は 50.2 となり, マイクロ市松パターンの対角線方向 $\left(50.3^{\circ}\right)$ と近い值と なった，そして，配向予想角度を含む範囲 $\left(45^{\circ}\right.$ から $\left.60^{\circ}\right)$ に配向を示し, $27.1 \%$ 細胞が存在していた.

（3） $10 \mu \mathrm{m}$ area では平均角度は $41.2^{\circ}$ となり, Control area と有意差は認められなかった. しかし, G1（37.5か ら $\left.52.5^{\circ}\right)$ において細胞の存在確率が $24.4 \%$ となり, 均等分布值（16.67\%）と比べて有意に高かった。 また, G6 $\left(0^{\circ}\right.$ から $7.5^{\circ}$ と $82.5^{\circ}$ から $\left.90^{\circ}\right)$ において細胞の存在確率が $8.5 \%$ となり, 均等分布值と比べて有意に低かった。一 方で, Control area ではすべての範囲において均等分布値と有意な差はなかった.

これらのことから，細胞の配向は接着基板表面模様のアスペクト比によって異なる影響を受けることが示唆さ れた. 今後, 隣接している細胞や分化後の細胞の検討を行うことで, 細胞の配向メカニズムについて詳細な検討 を行っていく. 


\begin{abstract}
謝 辞
本研究を行うにあたり, 文部科学省私立大学戦略的研究基盤形成支援事業(工学院大学 FMS)の支援を受けた. 謝意を表する.
\end{abstract}

\title{
References
}

Altomare, L., Gadegaard, N., Visai, L., Tanzi, M. C. and Farè, S., Biodegradable microgrooved polymeric surfaces obtained by photolithography for skeletal muscle cell orientation and myotube development, Acta Biomaterialia, Vol. 6, No. 6 (2010), pp. 1948-1957.

Charest, J. L., García, A. J. and King, W. P., Myoblast alignment and differentiation on cell culture substrates with microscale topography and model chemistries, Biomaterials, Vol. 28, No. 13 (2007), pp. 2202-2210.

Fujita, H., Dau, V. T., Shimizu, K., Hatsuda, R., Sugiyama, S. and Nagamori, E., Designing of a Si-MEMS device with an integrated skeletal muscle cell-based bio-actuator, Biomedical Microdevices, Vol. 13, No. 1 (2011), pp. 123-129.

Hino, H., Hashimoto, S. and Sato, F., Effect of micro ridges on orientation of cultured cell, Journal of Systemics, Cybernetics and Informatics, Vol. 12, No. 3 (2014), pp. 47-53.

In, H. Y., Co, C. C. and Ho, C. -C., Alteration of human neuroblastoma cell morphology and neurite extension with micropatterns, Biomaterials, Vol. 26, No. 33 (2005), pp. 6599-6609.

Lam, M. T., Sim, S., Zhu, X. and Takayama, S., The effect of continuous wavy micropatterns on silicone substrates on the alignment of skeletal muscle myoblasts and myotubes, Biomaterials, Vol. 27, No. 24 (2006), pp. 4340-4347.

Song, W., Lu, H., Kawazoe, N. and Chen, G., Adipogenic differentiation of individual mesenchymal stem cell on different geometric micropatterns, Langmuir, Vol. 27, No. 10 (2011), pp. 6155-6162.

Sugimoto, K., Yusuke, T., Hino, H. and Hashimoto, S., Effect of aspect ratio of checkered (Ichimatsu) convexo-concave micro-pattern on orientation of cultured cells, Proceedings of 20th World Multi-Conference on Systemics Cybernetics and Informatics, Vol. 2 (2016), pp. 141-146.

Tanaka, Y., Morishima, K., Shimizu, T., Kikuchi, A., Yamato, M., Okano, T. and Kitamori, T., An actuated pump on-chip powered by cultured cardiomyocytes, Lab on a Chip - Miniaturisation for Chemistry and Biology, Vol. 6, No. 3 (2006), pp. 362-368.

Wang, P. -Y., Yu, H. -T. and Tsai, W. -B., Modulation of alignment and differentiation of skeletal myoblasts by submicron ridges/grooves surface structure, Biotechnology and Bioengineering, Vol. 106, No. 2, 1 (2010), pp. 285-294. 